\title{
Genotoxic evaluation of sodium nitroprusside in Aspergillus nidulans
}

\author{
Simone Jurema Ruggeri Chiuchetta and Marialba Avezum Alves de Castro-Prado \\ Universidade Estadual de Maringá, Departamento de Biologia Celular e Genética, Maringá, PR, Brazil.
}

\begin{abstract}
The exogenous nitric oxide donor, sodium nitroprusside, evaluated the recombinogenic potential of nitric oxide. Drug inhibited mycelial growth and conidiation in A757 Aspergillus nidulans master strain. Two heterozygous diploid strains, one wild $\left(u v s H^{+} / / u v s H^{+}\right)$and the other defective to DNA repair (uvsH//uvsH) were used for recombinagenesis tests. Sodium nitroprusside recombinogenic effect was evaluated by the induction of homozygosis of recessive genes, originally present in heterozygous condition. Results show that sodium nitroprusside (40 $\mu \mathrm{M}, 80 \mu \mathrm{M}$ and $160 \mu \mathrm{M})$ is effective in inducing mitotic crossing-over in diploid cells of $A$. nidulans.
\end{abstract}

Key words: nitric oxide, parasexual cycle, homozygotization index, conidiation, mitotic recombination.

Received: September 24, 2004; Accepted: March 22, 2005.

\section{Introduction}

The loss of a functional copy of a heterozygous tumor suppressor gene represents an important step during neoplastic transformation. Considered as a somatic event, loss of heterozygosity ( $\mathrm{LOH}$ ) of the long arm of chromosome 13 is the most common mechanism by which the wild-type allele at the retinoblastoma tumor-suppressor locus $(R B 1)$ is lost in a heterozygous retinal cell for a null mutation. Retinoblastoma may arise from the resulting daughter cell which will be either homozygous or hemizygous for the mutant allele (Hagstrom and Dryja, 1999; Ramel et al., 1996).

Several pathways, including chromosomal deletion, mitotic non-disjunction and mitotic recombination, may lead to LOH (Petek et al., 2003; Lasko et al., 1991). Mitotic recombination consists of exchange events between homologous chromosomes that, following chromosome segregation and cell division, may result in homozygosis of distal genes to the point of exchange (Biggins and Murray, 1999; Beumer et al., 1998). This process plays an essential role in the DNA repair mechanism of eukaryotic cells (Seoighe and Wolfe, 1998; Wolfe and Shields, 1997) and may be initiated by double- or single-strand breaks (Biggins and Murray, 1999; Galli and Schiestl, 1998; Geigl and Eckardt-Sxhupp, 1991).

Although the genetic control of mitotic recombination is poorly understood, it is known to increase in eukaryotic cells in response to a variety of DNA-damaging

Send correspondence to M.A.A. Castro-Prado, Universidade Estadual de Maringá, Departamento de Biologia Celular e Genética, Av. Colombo 5790, 87020-900 Maringá, PR, Brazil. E-mail: maacprado@uem.br. agents such as ionizing and non-ionizing radiation and chemical substances (Becker et al., 2003; Geigl and Eckardt-Schupp, 1991; Takabayashi et al., 1984). Intercalating agents such as cryptolepine that induce breaks in DNA and inhibitors of DNA synthesis such as danofloxacin are in fact known as recombinagenic effectors (Chiuchetta and Castro-Prado, 2002; Leonardo and Castro-Prado, 2001).

The free radical gas nitric oxide (NO) acts as a transcellular messenger molecule in both physiological and pathological processes in humans, including inflammation and cancer (Lala and Orucevic, 1998; Moncada et al., 1991; Collier and Vallance, 1989). The gaseous molecule is synthesized by nitric oxide synthase (NOS) from L-arginine (L-Arg) and has been shown to have tumor promoting and inhibitory effects (Xu et al., 2002; Brennan and Moncada, 2002). In the intracellular environment nitric oxide is a highly reactive molecule causing DNA damage via the generation of peroxynitrite (ONOO-), which can cause DNA single-strand breaks, and nitrogen trioxide $\left(\mathrm{N}_{2} \mathrm{O}_{3}\right)$, which can cause DNA-crosslinking. One of the consequences of nitric oxide mediated DNA damage is to trigger accumulation of the p53 which may lead to cell cycle arrest and cellular apoptosis, this being a possible pathway by which nitric oxide may exert anti-tumor properties (Xu et al., 2002; Forrester et al., 1996; Wink et al., 1991). Alternatively, nitric oxide generated by NOS may stimulate tumor growth and metastasis by promoting new blood vessel formation through the up-regulation of vascular endothelial growth factor (VEGF), a glycoprotein that causes increased mitosis in endothelial cells (Lala and Chakraborty, 2001; Moochhala and Rajnakova, 1999). 
Sodium nitroprusside ( $\mathrm{SN}$ ) is a nitric oxide donor which can cause DNA single-strand breaks resulting in mitotic crossing-over. This chemical was recently suggested as a treatment for cerebral ischemia in patients with severe, medically refractory vasospasm after subarachnoid hemorrhage (Raabe et al., 2002). Vasodilating therapy with sodium nitroprusside has also proven effective in patients with left ventricle failure, but arterial hypotension is its main side effect (Bregagnollo et al., 1999).

The filamentous fungus Aspergillus nidulans has often been used in mitotic crossing-over studies because this fungus spends a substantial proportion of its life cycle in the G2 phase (Bergen and Morris, 1983). Our research investigated the recombinogenic potential of the nitric oxide donor sodium nitroprusside in diploid Aspergillus nidulans. strains

\section{Material and Methods}

\section{Fungal strains and culture media}

The origin and the genotypes of the $A$. nidulans strains used in this study are shown in Table 1, the DNA repair proficient diploid strain UT448//A757 and the DNA repair deficient diploid strain B211//A837 being prepared according to the method of Roper (1952). Czapek-Dox medium supplemented with $1 \%(\mathrm{w} / \mathrm{v})$ glucose was used as the Minimal Medium (MM) while the Complete Medium (CM) was that described by Pontecorvo et al. (1953) and Van de Vate and Jansen (1978). Supplemented medium (SM) consisted of MM plus the nutrients required by each strain. Solid medium contained 1.5\% (w/v) agar.

\section{Evaluation of sodium nitroprusside toxicity}

Conidia of $A$. nidulans haploid strain A757, derived from colonies grown in CM, were inoculated at the center of six CM plates (the control group) and six plates containing CM supplemented with various concentrations (40, 80, 160 or $320 \mu \mathrm{M})$ of sodium nitroprusside $(\mathrm{CM}+\mathrm{SN})$ (the ex-

Table 1 - Genotype and origin of Aspergillus nidulans strains.

\begin{tabular}{llc}
\hline Strains & Genotype $^{\$}$ & Origin $^{\#}$ \\
\hline UT448 & $\begin{array}{l}\text { riboA1, pabaA124, biA1 (I); AcrA1, } \\
\text { wA2 (II) }\end{array}$ & Utrecht Stocks $^{\text {B }}$ \\
B211 & $\begin{array}{l}\text { yA2; biA1; AcrA1; wA2; methA17; } \\
\text { uvsH77, pyroA4, chaA1 }\end{array}$ & LGM \\
A837 & pabaA1, uvsH77, pyroA4, choA1, chaA1 & FGSC \\
A757 & $y A 2$, methA17, pyroA4 & FGSC \\
\hline
\end{tabular}

${ }^{\$}$ Mutant allele phenotypes. Requirement for: riboflavin $=r i b o A 1 ; p$-aminobenzoic acid $=$ pabaA124 or pabaA1; biotin = biA1; methionine $=$ methA17; pyridoxine $=$ pyro 44 ; and choline $=$ choA1 . Conidia color: chartreuse $=c h a ; w=$ white; and $y=$ yellow. Miscellaneous: Acriflavine resistance $=$ AcrA1; sensitivity to UV light $=u v s H 77$.

${ }^{\#}$ FGCS = Fungal Genetic Stock Center, University of Kansas Medical Center, Kansas USA; LGM = Laboratory of Genetics of Microrganisms, State University of Maringá, Maringá, Paraná, Brazil. perimental group). The plates were incubated at $37^{\circ} \mathrm{C}$ and the diameter of the colonies measured after 24, 48, 72, 96 and $120 \mathrm{~h}$ incubation. The growth rates of the control and experimental groups were compared using the Student's $t$ test at $\mathrm{p}<0.05$.

\section{Spore production}

Conidia from strain A757, derived from colonies grown in $\mathrm{CM}$, were inoculated at the center of six plates containing $\mathrm{CM}$ (the control group) and six containing $\mathrm{CM}+\mathrm{SN}$ (the experimental group) (40 to $320 \mu \mathrm{M})$ which were incubated for $24 \mathrm{~h}$ at $37^{\circ} \mathrm{C}$. After incubation spore production was determined by washing each plate with $15 \mathrm{~mL}$ of $0.01 \%(\mathrm{w} / \mathrm{v})$ Tween 80 and 20 sterilized glass beads $(3 \mathrm{~mm} \phi)$ to produce a suspension of conidia which were counted using a haemacytometer. Results for the control and experimental groups were compared using the Student's $t$ test at $\mathrm{p}<0.05$.

\section{Calculating homozygotization index}

Conidia of the diploid $A$. nidulans strains (UT448//A757 and B211//A837) were individually inoculated onto $\mathrm{MM}+\mathrm{SN}$ plates containing different concentrations of sodium nitroprusside $(40,80$ or $160 \mu \mathrm{M})$ and incubated for 5 days at $37^{\circ} \mathrm{C}$. This treatment produced 19 visible mitotic morphologically identifiable diploid sectors (D1 to D19) which differed from the original diploid strain. The sectors were homozygous $(+/+)$ or heterozygous $(+/-$ or $-/+$ ) diploids but never recessive homozygotes (-/-) because these cannot grow on MM. The new diploid strains (D1 to D19) were purified on MM, individually transferred to CM plates and processed by spontaneous haploidization. After haploidization, the haploid mitotic segregants, obtained from diploids D1-D18, were purified in CM and their mitotic stability evaluated. Only mitotically stable segregants at the final stage were selected for the recombinagenesis test (Chiuchetta and Castro-Prado, 2002).

For the recombinagenesis tests conidia of each haploid segregant were individually transferred to 25 positions on CM plates and incubated for $48 \mathrm{~h}$, after which colonies were transferred to different supplemented media: MM supplemented with all of the nutritional requirements of the master strains (UT448 and UT196 or B211 and A837), being omitted one of them, in each type of medium. Mitotic crossing-over causes homozygotization of heterozygous-conditioned genes. If sodium nitroprusside induces mitotic crossing-over in diploid strains UT448//A757 and B211//A837 only heterozygotes (+/- or -/+) or homozygotes $(+/+)$ diploids will develop in Minimal Medium and the nutritional markers will segregate among the haploids in the proportion of $4+$ to 2 - but if sodium nitroprusside does not induce crossing-over the proportion will be $4+$ to 4- because the initial selection process limits the growth of -/- diploids. The ratio of prototrophic to auxotrophic segregants is described by the Homozygotization Index 
(HI), a HI value equal to or higher than 2 indicating that sodium nitroprusside has recombinogenic effects (Pires and Zucchi, 1994). The recombinogenic potential of sodium nitroprusside was assessed by comparing the homozygotization indices of the $p$-aminobenzoic acid (paba), biotin (bi), methionine (meth) and pyridoxine (pyro) genes using the Chi-squared $\left(\chi^{2}\right)$ test with the Yates correction and $\mathrm{p}<0.05$.

\section{Results and Discussion}

We found that, as compared to controls which received no sodium nitroprusside, 40 to $320 \mu \mathrm{M}$ of sodium nitroprusside modified the mycelial growth of strain A757 and reduced the conidia production (Table 2, Figure 1) but did not affect the temporal development of cells (data not shown), these results being in agreement with those of Ninnemann and Maier (1996) who demonstrated sodium nitroprusside inhibited conidiation in Neurospora crassa.

Conidiation in $A$. nidulans requires a transition from the polarized growth pattern of vegetative hyphae to apolar budding of uninuclear cells. The products of at least two

Table 2 - Influence of 40 to $320 \mu \mathrm{M}$ of sodium nitroprusside on conidiation in Aspergillus nidulans strain A757.

\begin{tabular}{cccccc}
\hline & \multicolumn{5}{c}{ Sodium nitroprusside concentration $(\mu \mathrm{M})$} \\
\cline { 2 - 6 } & $0^{\#}$ & 40 & 80 & 160 & 320 \\
\hline Conidia per $\mathrm{mL} \times 10^{3}$ & 720.6 & $235.6^{*}$ & $149.4^{*}$ & $8.1^{*}$ & $7.0^{*}$ \\
\hline
\end{tabular}

\section{${ }^{*}$ Control.}

*Significantly different from control (Student's $t$ test, $\mathrm{p}<0.05$ ). The arithmetic mean of four experiments was estimated for each treatment.

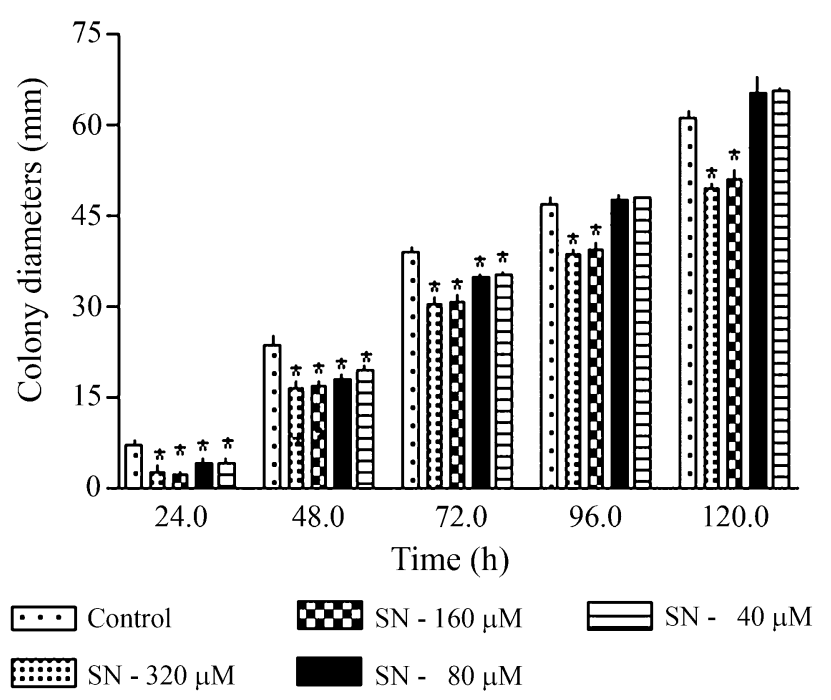

Figure 1 - Growth of $A$. nidulans strain A757 on plates containing Complete Medium plus various concentrations (0 (control), 40, 80, 160 and $320 \mu \mathrm{M})$ of sodium nitroprusside. An asterisk (*) indicates that growth was significantly different from the control $(t$ test, $\mathrm{p}<0.05)$. major regulatory genes, $\operatorname{brl} A$ (bristle) and $s t u A$ (stunted), are transcription factor proteins that regulate the asexual sporulation in A. nidulans (Timberlake and Clutterbuck, 1994; Wu and Miller, 1997). The brlA gene encodes a $\mathrm{C}_{2} \mathrm{H}_{2}$ zinc finger protein mediating the transition from polarized to radial growth at the stalk apex of the asexual sporeforming conidiophore to form the conidiophore vesicle (Aguirre, 1993; Adams et al., 1988) while regulated stuA expression is required for correct cell-pattern formation during asexual reproduction (Wu and Miller, 1997). We suggest that alterations in $A$. nidulans conidiation induced by sodium nitroprusside may be due to nitric oxide impairing the transcriptional activation of structural sporulationspecific genes. It has already been shown that nitric oxide inhibits both the DNA binding activity of yeast zinc finger LAC9 and non-zinc finger CPF-1 transcription factors (Kröncke, 2001; Berendji et al., 1999; Kröncke et al., 1994).

We evaluated the recombinogenic potential of sodium nitroprusside towards $A$. nidulans diploid strains UT448//A757 (repair proficient) and A837//B211 (repair deficient) using the homozygotization index of various nutritional markers, homozygotization indices for the bi, paba and pyro genes being significantly higher in diploid strains treated with sodium nitroprusside (strains D2 to D4 and D6 to D18) as compared to untreated control strains (Tables 3 and 4). Diploid strains D1 and D5, derived from strain UT448//A757 treated with sodium nitroprusside, showed homozygotization indices of greater than 2 for the paba and bi genes but these results were not statistically significant (Table 3). In contrast, however, all the diploid strains obtained after sodium nitroprusside treatment of strain A837//B211 (strains D10 to D18) showed bi, paba and pyro genes homozygotization indices higher than 2 and significantly different from control values (Table 4). Kafer and Mayor (1986) and Yoon et al. (1995) showed that postreplication repair deficient $A$. nidulans $u v s H$ mutants such as strains A837 and B211 have a high frequency of spontaneous mitotic recombination in homozygous condition, a fact which explains the higher sodium nitroprusside sensitivity of the repair deficient diploid strain A837//B211 than the repair proficient strain UT448//A757.

We obtained meth gene homozygotization indices of less than 2 for A837//B211 strains D10 to D18 (Table 4) and this may have been due to the greater number of white (w) segregants isolated after haploidization, because in $A$. nidulans strain B211 the $w$ gene is closely linked to the meth gene and consequently most of the $w$ segregants have the meth phenotype.

Although auxotrophic diploids (-/-) are not selected for in Minimal Media supplemented with sodium nitroprusside, recessive homozygous diploids may be obtained for coloration markers of conidia such as the $w$ gene. In our experiments only prototrophic diploids with chartreuse conidia (cha//cha) were isolated from diploid B211//A837 

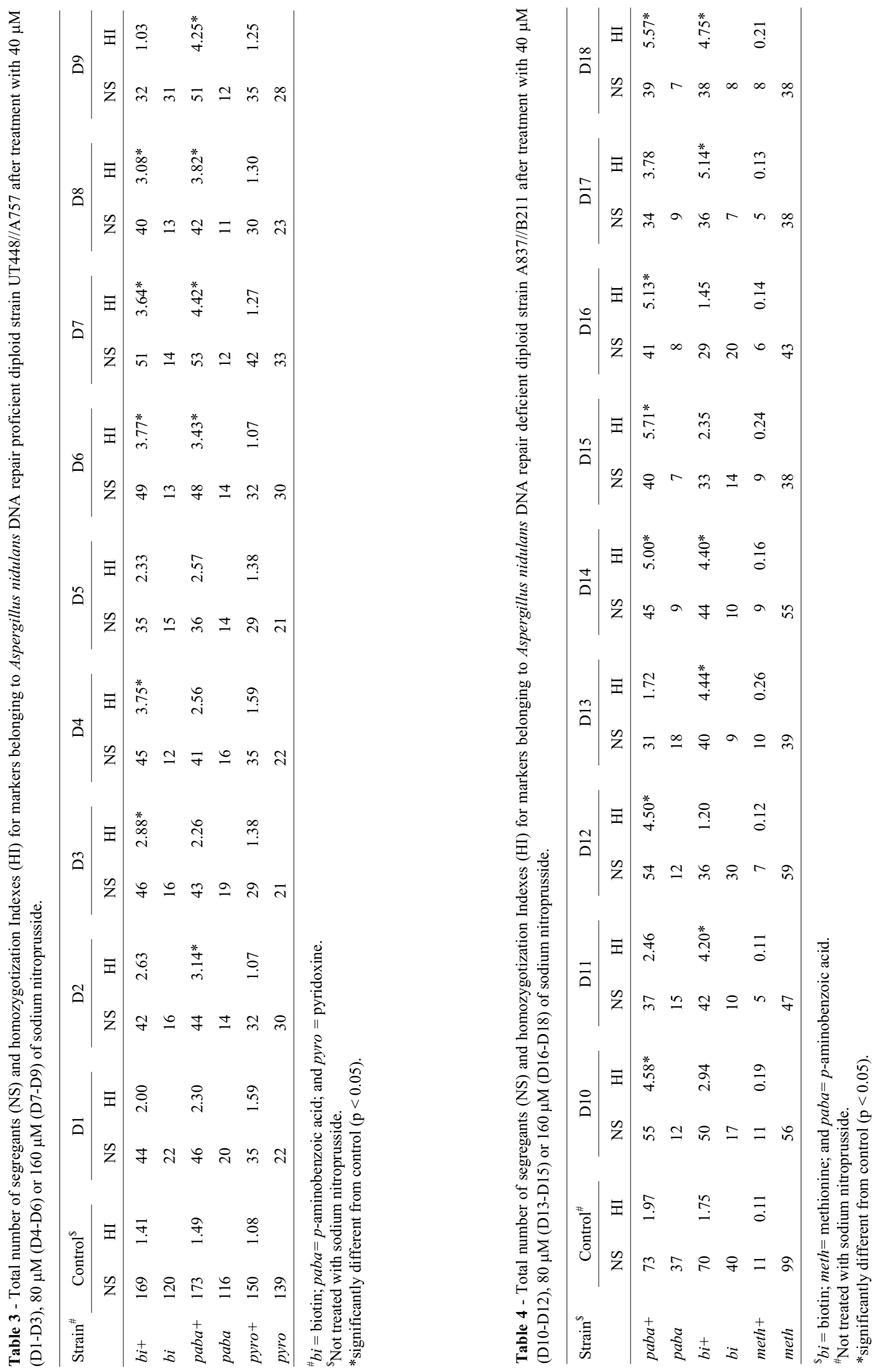
treated with sodium nitroprusside, although prototrophic diploids with green $(y+/ / y)$ and white $(w / / w)$ conidia were isolated from colonies of diploid UT448//A757 treated with sodium nitroprusside. Phenotypic analysis showed diploid D19 (white) to be a recombinant for the centromere-meth interval of chromosome II (Figure 2).

The recombinogenic effect of sodium nitroprusside in diploid $A$. nidulans cells may reflect a direct genotoxic effect of nitric oxide on DNA, stimulating the occurrence of DNA breaks during the G2 period. It is also possible that the same genotoxicity effect operates in mammalian cells and may contribute towards the nitric oxide tumor promoting effect.

The transformation of normal human cells into cancer cells is a multistep process and mitotic recombination is a factor that may be involved in the overall transformation process. Since mitotic crossing-over promotes homozygotization of recessive genes, studies have been developed to identify possible recombinogenic agents. Our results show
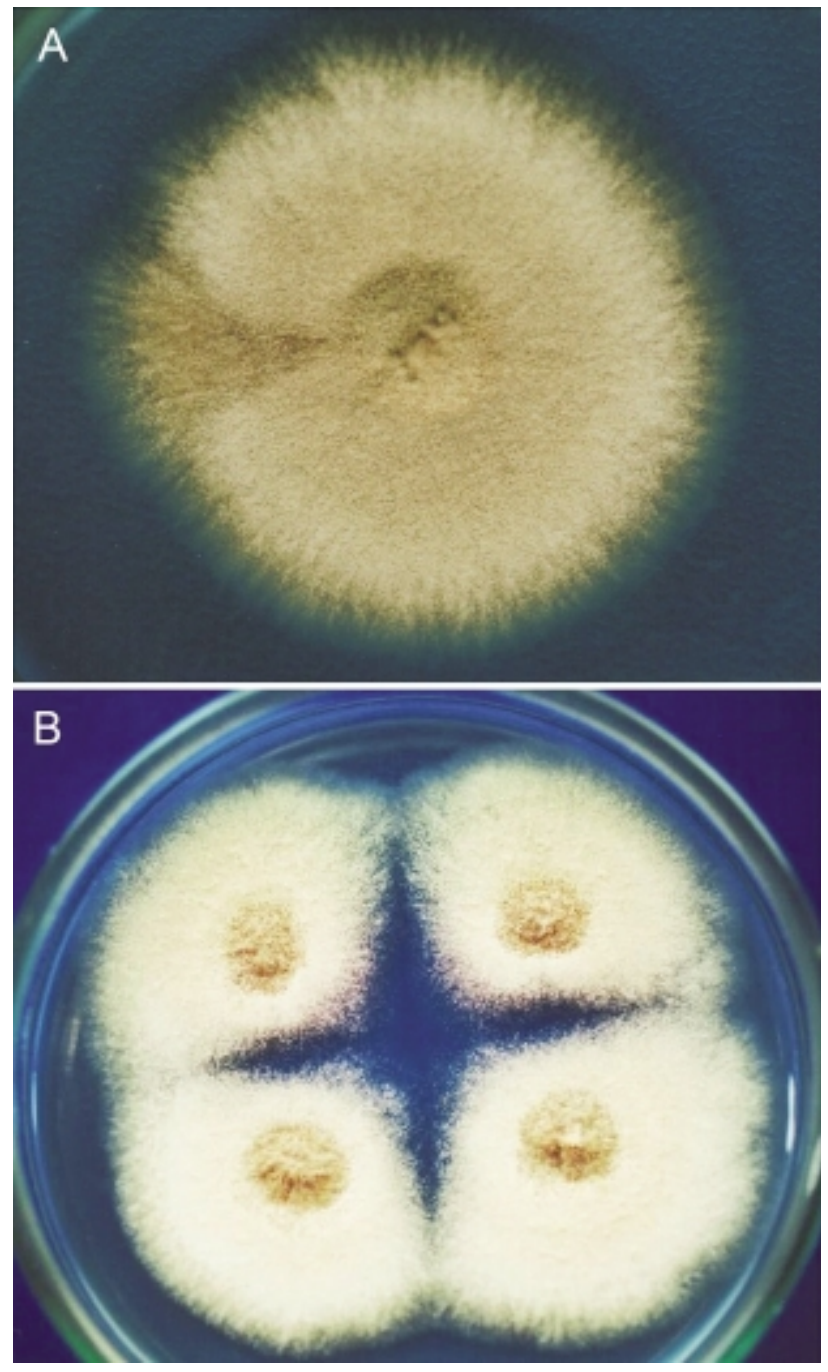

Figure 2 - (A) Mitotic instability of diploid strain D19 obtained after sodium nitroprusside treatment $(160 \mu \mathrm{M})$ of diploid strain UT448//A757; (B) stable mitotic segregant derived from strain D19. that at concentrations between $40 \mu \mathrm{M}$ to $160 \mu \mathrm{M}$ the nitric oxide donor sodium nitroprusside is efficient at inducing mitotic crossing-over in diploid strains of $A$. nidulans.

\section{References}

Adams TH, Boylan MT and Timberlake WE (1988) BrlA is necessary and sufficient to direct conidiophore development in Aspergillus nidulans. Cell 54:353-362.

Aguirre J (1993) Spatial and temporal controls of the Aspergillus brlA developmental regulatory gene. Mol Microbiol 8:211218.

Becker TCA, Chiuchetta SJR, Baptista F and Castro-Prado MAA (2003) Increase in mitotic recombination in diploid cells of Aspergillus nidulans in response to ethidium bromide. Genet Mol Biol 26:381-385.

Berendji D, Kolb-Bachofen V, Zipfel PF, Skerka C, Carlberg C and Kröncke KD (1999) Zinc finger transcription factors as molecular targets for nitric oxide-mediated immunosuppression: Inhibition of IL-2 gene expression in murine lymphocytes. Mol Med 5:721-730.

Bergen GG and Morris NR (1983) Kinetics of the nuclear division cycle of Aspergillus nidulans. J Bacteriol 156:155-160.

Beumer KJ, Pimpinelli S and Golic KG (1998) Induced chromosomal exchange directs the segregation of recombinant chromatids in mitosis of Drosophila. Genet 150:173-188.

Biggins S and Murray AW (1999) Sister chromatid cohesion in mitosis. Curr Opin Genet Dev 9:230-236.

Bregagnollo EA, Fortes AH and Cicogna AC (1999) Assessment of inotropic and vasodilating effects of milrinone lactate in patients with dilated cardiomyopathy and severe heart failure. Arq Bras Cardiol 72:155-160.

Brennan PA and Moncada S (2002) From pollutant gas to biological messenger: The diverse actions of nitric oxide in cancer. Ann R Coll Surg Engl 84:75-78.

Collier J and Vallance P (1989) Second messenger role for NO widens to nervous and immune systems. Trends Pharmacol Sci 10:427-431.

Chiuchetta SJR and Castro-Prado MAA (2002) Recombinagenic effect of cryptolepine in $u v s H^{+} / / u v s H^{+}$and $u v s H / / u v s H$ diploid strains of Aspergillus nidulans. Folia Microbiol 47:516-520.

Forrester K, Ambs S, Lupold SE, Kapust RB, Spillare EA, Weinberg WC, Felley-Bosco E, Wang XW, Geller DA, Tzeng E, Billiar TR and Harris CC (1996) Nitric oxide-induced p53 accumulation and regulation of inducible nitric oxide synthase expression by wild-type p53. Proc Natl Acad Sci USA 93:2442-2447.

Galli A and Schiestl RH (1998) Effects of DNA-double-strand and single-strand breaks on intrachromosomal recombination events in cell-cycle-arrested yeast cells. Genet 149:1235-1250.

Geigl EM and Eckardt-Schupp F (1991) Repair of gamma Rayinduced S1 nuclease hypersensitive sites in yeast depends on homologous mitotic recombination and a RAD18-dependent function. Curr Genet 20:33-7.

Hagstrom SA and Dryja TP (1999) Mitotic recombination map of 13cen-13q14 derived from na investigation of loss of heterozygosity in retinoblastomas. Proc Natl Acad USA 96:29522957. 
Kafer E and Mayor M (1986) Genetic analysis of DNA repair in Aspergillus: Evidence of different types of MMS sensitive hyperrec mutants. Mutat Res 161:119-134.

Kröncke KD (2001) Zinc-finger proteins as molecular targets for nitric oxide-mediated gene regulation. Antiox Red Sig 3:565-575.

Kröncke KD, Fschsel K, Schmidt T, Zenke FT, Dasting I, Wesener JR, Bettermann H, Breunig KD and Kolb-Bachofen V (1994) Nitric oxide destroys zinc-sulfur clusters inducing zinc release from letallothionein and inhibition of the zinc finger-type yeast transcription activator LAC9. Biochem Biophys Res Commun 200:1105-1110.

Lala PK and Chakraborty C (2001) Role of nitric oxide in carcinogenesis and tumor progression. Lancet Oncol 2:149-156.

Lala PK and Orucevic A (1998) Role of nitric oxide in tumor progression: Lessons from experimental tumors. Cancer Metastasis Rev 17:91-106.

Lasko D, Cavenee W and Nordenskjold M (1991) Loss of constitutional heterozygosity in human cancer. Ann Rev Genet 25:281-314.

Leonardo A and Castro-Prado MAA (2001) Evaluation of the recombinogenic activity of danofloxacin in diploid cells of Aspergillus nidulans. Arq Bras Med Vet Zootec 53:130-135.

Moncada S, Palmer RM and Higgs EA (1991) Nitric oxide: Physiology, pathophysiology and pharmacology. Pharmacol Rev 43:109-142.

Moochhala S and Rajnakova A (1999) Role of nitric oxide in cancer biology. Free Radic Res 31:671-679.

Ninnemann H and Maier J (1996) Indications for the occurrence of nitric oxide synthases in fungi and plants and the involvement in photoconidiation of Neurospora crassa. Photochem and Photobiol 64:393-398.

Petek E, Jenne DE, Smolle J, Binder B, Lasinger W, Windpassinger C, Wagner K, Kroisel PM and Kehrer-Sawatzki H (2003) Mitotic recombination mediated by the JJAZF1 (KIAA0160) gene causing somatic mosaicism and a new type of constitutional NF1 microdeletion in two children of a mosaic female with only few manifestations. J Med Genet 40:520-525.

Pires LTA and Zucchi TMAD (1994) A new method to detect potential genotoxic agents using mitotic crossing-over in diploid strains of Aspergillus nidulans. Braz J Genet 17:371-376.
Pontecorvo G, Roper JA, H emmons LM, Macdonald KD and Bufton AW (1953) The genetics of Aspergillus nidulans. Adv Genet 5:141-238.

Raabe A, Zimmermann M, Stzer M, Vatter H, Berkefeld J and Seifert V (2002) Effect of intraventricular sodium nitroprusside on cerebral hemodynamics and oxygenation in poor-grade aneurysm patients with severe, medically refractory vasospasm. Neurosurgery 50:1006-10013.

Ramel C, Cederberg H, Magnusson J, Vogel E, Natarajan AT, Mullender LH, Nivard JM, Parry JM, Leyson A, Comendador MA, Sierra LM, Ferreiro JA and Consuegra S (1998) Somatic recombination, gene amplification and cancer. Mutat Res 353:85-107.

Roper JA (1952) Production of heterozygous diploids in filamentous fungi. Experientia 8:14-15.

Seoighe C and Wolfe KH (1998) Extent of genomic rearrangement after genome duplication in yeast. Proc Natl Acad Sci USA 95:4447-4452.

Takabayashi T, Lin MS and Wilson MG (1984) Ultraviolet light and mitomycin $\mathrm{C}$ induced sister-chromatid exchanges in fibroblasts from patients with retinoblastoma. Mut Res 141:101-104.

Timberlake WE and Clutterbuck AJ (1994) Genetic regulation of conidiation. In: Martinelli SD and Kinghorn JR (eds) Aspergillus: 50 years On. Elsevier, New York, pp 383-427.

Van De Vate C and Jansen GJO (1978) Meiotic recombination in a duplication strain of Aspergillus nidulans. Genet Res 31:29-52.

Wink DA, Kasprzak KS, Maragos CM, Elespuru RK, Misra M, Dunams TM, Cebula TA, Koch WH, Andrews AW and Allen JS (1991) DNA deaminating ability and genotoxicity of nitric oxide and its progenitors. Science 254:1001-1003.

Wolfe KH and Shields DC (1997) Molecular evidence for an ancient duplication of the entire yeast genome. Nature 387:708-713.

Wu J and Miller BL (1997) Aspergillus asexual reproduction and sexual reproduction are differentially affected by transcriptional and translational mechanisms regulating stunted gene expression. Mol Cel Biol 17:6191-6201.

Xu W, Liu LZ, Loizidou M, Ahmed M and Charles IG (2002) The role of nitric oxide in cancer. Cell Res 12:311-320.

Yoon JH, Lee BJ and Kang HS (1995) The Aspergillus uvsH encodes a product homologous to yeast $R A D 18$ and Neurospora UVS-2. Mol Gen Genet 248:174-181. Associate Editor: Sérgio Olavo Pinto da Costa 